\title{
Media Scrutiny of Higher Education: An Ongoing Challenge and Long-term Trend
}

Received (in revised form): August 10, 2003

\section{Anthony C. Peyronel}

is an assistant professor and undergraduate program coordinator in the Department of Speech and Communication Studies at Edinboro University of Pennsylvania. He also serves as faculty advisor to the Edinboro University chapter of the Public Relations Student Society of America (PRSSA). Before joining the Edinboro faculty, he worked as a reporter with the Kittanning (PA) Leader-Times, as a public relations writer at Penn State University, and as Director of Communications at Westminster College in New Wilmington, PA. He holds a doctorate in higher education administration from the University of Pittsburgh.

\begin{abstract}
Increasing skepticism was identified as a key trend in a recent American Journalism Review assessment of media coverage of higher education. However, this trend is hardly new, as American colleges and universities have been subjected to intense media scrutiny for at least the last two decades. This article examines the frequently adversarial relationship that exists between higher education and the media, concluding that despite increasing media skepticism, media relations should still be a key component of an institution's integrated marketing efforts.

\section{Keywords:}

media, higher education, college and university public relations professionals, integrated marketing communications
\end{abstract}

\footnotetext{
Author's Contact Address:

Anthony Peyronel

Dept of Speech and Communication Studies

Edinboro University of Pennsylvania

Edinboro, PA 16444, USA

Tel: +1 8147322166

Fax: +1814732 2270

Email: apeyronel@edinboro.edu
}

\section{Introduction}

In a recent American Journalism Review assessment of media coverage of higher education, Stepp ${ }^{1}$ found that journalists are becoming increasingly skeptical in their coverage of America's colleges and universities. However, it is misleading to regard this media skepticism as something new. Indeed, American higher education has been subjected to increasing levels of media scrutiny for at least two decades. This pattern seems to indicate that intense media coverage is here to stay, and that colleges and universities should be prepared to deal with it through effective media relations.

\section{A History of Higher Examination}

Stepp $^{2}$ is clearly on the mark in terms of his assessment of the current relationship between higher education and the media. Examples of media scrutiny abound, ranging from the Boston Globe's Pulitzer Prize-nominated series on grade inflation at Harvard to a freedom of information battle between a Houston Chronicle reporter 
and the University of Texas over access to that state system's investment policies. However, it is inaccurate to describe this aggressive coverage of colleges and universities as a "new skepticism: In an age of accountability, as tuition surges and consumers squeal, colleges have begun sliding off the pedestals they once occupied as privileged, seldom-challenged local shrines." 3 In actuality, this slide began years ago. In fact, university relations executive Roger Williams offered a strikingly similar proclamation more than a decade ago:

Higher education was the last major American institution to fall from grace. We had a nice, protected status until the late 1980s, when a series of unrelated incidents from misreporting the use of government funds to scientific fraud, animal welfare and the so-called tuition price-fixing began to undermine public confidence in higher education. ${ }^{4}$

Dennis and Lamay believe the intense media scrutiny can be traced back to the days of the Reagan Administration and the attacks of then-Education Secretary William Bennett. ${ }^{5}$ Those attacks spawned an array of public critics such as Charles Sykes and Dinesh D'Souza, which helped propel the rising tide of skepticism into the 1990s. ${ }^{6}$

In a content analysis of seven of the nation's largest newspapers, Ratcliffe and Williams found that media coverage of higher education increased significantly between 1987 and 1992, citing an increasingly skeptical public as the primary reason for the increase in coverage. ${ }^{7}$ The researchers also found that rising college costs and the impact of tuition increases on accessibility were the most common theme in editorials and opinion pieces. Three studies conducted in the mid-1990s by the American Council on Education indicated that the tough media coverage was driven by an increasingly skeptical public who had significant concerns about issues such as cost, affordability, and educational quality. ${ }^{8}$

After nearly 20 years, one could logically conclude that increasing media scrutiny of higher education is a long-term trend. And after all that time, it appears that many of the issues that attracted media attention two decades ago-cost, finances, accessibility-remain critical issues today, according to Scott Jaschik, editor of The Chronicle of Higher Education: "The biggest trend, I think, is to cover higher education as a consumer topic. The questions are, 'Where is my kid going to get into college?' 'How am I going to pay for it?' and 'Is my kid going to get a job afterward?", 9

Again, consumerism in higher education is clearly becoming a long-term trend. Many colleges and universities first became concerned with institutional assessment during the late 1980s, an issue Daughdrill believes was motivated by an increasing pressure to be accountable, as higher education's consumers began to ask "Are we getting our money's worth?"10

Higher education institutions were forced, not only to assess their own effectiveness, but also to improve relations with a myriad of key stakeholders. In what was perhaps a precursor to today's integrated marketing communications movement, Burness argued that the relationship between the media and higher education had so deteriorated that pursuing an aggressive media relations 
program was no longer worth the effort. ${ }^{11}$ Instead, he recommended that college and university public relations offices focus on communicating directly with alumni, parents, government officials and other key publics.

\section{Media Relations in the New Millennium}

As this adversarial relationship between higher education and the media has continued, many colleges and universities have embraced integrated marketing communication, which Sands defines as "a systematic approach to developing, delivering, managing, and evaluating a wide range of institutional messages that are sent from various departments to various audiences." ${ }^{12}$ He cites an increasingly aggressive news media and a growing public demand for accountability as two of the primary drivers of the ICM movement.

Hale says college and university public relations practitioners must take the lead in such institutional marketing efforts and, in doing so, place less emphasis on media relations. ${ }^{13}$ Indeed, he calls for the closing of university news bureaus and abandonment of the "journalist-inresidence" mindset that characterizes the media relations programs of many colleges and universities:

We have oversold the importance and value of publicity and we have staunchly defended our news bureaus, whose functions and focus have been outdated for two decades. Veterans of the publicity game know you can never get enough press coverage, and no matter how effective you are, watch out for that school across town that always seems to do a little better in the eyes of your president and your alumni. Some of us seem to be quite happy being pigeon-holed as in-house journalists who track down all of that exciting news on campus and disseminate it to a world hungry for information about our latest curricular innovation. ${ }^{14}$

While the primary argument made by both Sands and Hale is that higher education public relations professionals must become more involved in institutional decision making and setting institutional policy, ${ }^{15}$ it must be pointed out that an aggressive media relations program can still be a significant part of a college or university's overall public relations efforts. Biagi reports that, although the American public generally read fewer newspapers and watched less television news during the 1990s, a recent study by the Pew Research Center for the People and the Press indicates that Americans regard news organizations as credible sources of information. ${ }^{16}$

The Pew study asked respondents to assign one of four rankings, with 4 being "most credible" and 1 being "cannot believe," to various print and electronic news sources. In this assessment of the believability of news organizations, 65 percent of respondents gave a ranking of 3 or 4 to their "daily newspaper" and 74 percent of respondents assigned the two highest rankings to local television news. Overall, The Wall Street Journal and CNN, two leading national news organizations, rated even higher at 78 percent. $^{17}$

Moreover, an important secondary finding in Stepp's analysis of media coverage of higher education is that news organizations, faced with shrinking resources, tend to neglect higher education coverage during tough economic times. Of 
more than 500 reporters who belonged to the Education Writers Association in 2002, only 45 listed themselves as full-time on higher education, and there are even fewer broadcast journalists covering the higher education beat. ${ }^{18}$ With resources for covering higher education stretched thin, this could be the perfect opportunity for colleges and universities to use effective media relations to increase positive media coverage.

In good economic times and in bad, Jones argues that media relations is a critical element of any integrated marketing strategy:

In the age of integrated marketing, a solid media relations program is as important as it ever has been in higher education advancement. Media relations is only one arrow in the quiver carried by university marketers, but it is a remarkable tool. Use it well and you can help set your institution apart from your competitors, boost internal morale, and position your institution for success. ${ }^{19}$

Jones believes positive media coverage is critical because it provides a third-party endorsement of importance and quality, helps develop name recognition, and builds support among key publics such as donors and alumni. ${ }^{20}$ Ross and Halstead, while acknowledging the limitations of media relations, add that university presidents and trustees "are steadfast in their belief in the primacy of news media as a public relations tool." 21 In their book Public Relations and the Presidency, the editors include at least a half dozen case studies of colleges and universities that used effective media relations to help meet some important institutional goal.
While an aggressive media relations program is essential, it is the specific components that are included in that program that will determine its effectiveness. As Hale points out, simply counting the number of news releases that are mass mailed to media outlets is not the best way to assess a public relations operation.

Ross and Halstead advocate four primary approaches that include targeted news releases on relevant topics, providing faculty members as expert sources on breaking stories, hometown news releases that highlight localized student achievement, and op-ed pieces that showcase faculty expertise. ${ }^{23}$ While Jones also recommends plugging faculty experts into the media's news agenda as sources and utilizing news releases for disseminating spot news stories on campus, he cautions against the overuse of news releases. ${ }^{24}$ In addition, Jones suggests building personal contacts among editors and reporters so that stories are specifically targeted to interested media, rather than mass mailed through impersonal distribution lists. He also notes that the individual reporter's preferred method of receiving story ideasbe it by news release, personal letter, telephone call, email, or face-to-face meeting-automatically becomes the "right" way to disseminate the information. ${ }^{25}$

College and university public relations professionals should also keep in mind that all these tactics, when carried out appropriately, are designed to make the job of journalists easier. This point is especially critical when considering that newsrooms are often understaffed and higher education beats are sometimes uncovered. 
Another important point to remember is that how an institution of higher education handles bad news is often more important than how it promotes good news. Ross and Halstead and Jones agree that credibility is the key ingredient for maintaining a positive relationship with the media, especially in an age of media scrutiny. ${ }^{26}$ While Jones believes most campus public relations professionals understand this maxim, some campus leaders do not:

Leaders of institutions who actively seek positive coverage from the media need to understand that when they do so, they are opening up the institution in bad times as well as good times. The same education editor who did such a fine story on your institution's student volunteer service programs will expect you to respond just as quickly when she calls about citizens' complaints to city council about noisy parties in student apartments. You can't welcome the media with open arms for good stories and brush them off for the bad ones. If you do, you will suddenly find there is no more interest in your stories. ${ }^{27}$

\section{Conclusion}

American higher education has been subjected to increasing levels of media scrutiny for at least the last 20 years. Consequently, colleges and universities must be prepared to deal with what is clearly a long-term trend.

At times, the relationship between higher education and the media has been so adversarial that some have advocated abandoning media relations and placing more emphasis on directly communicating with students, alumni, and other key publics. In actuality, however, an effective media relations program is more important than ever for colleges and universities. With tough economic times forcing many newsrooms to commit fewer resources to covering higher education, college and university public relations professionals would be well advised to make certain that media relations plays a key role in any integrated marketing efforts.

\section{References}

1. C. S. Stepp (2003), "Higher examination," American Journalism Review, January/February, pp. 18-25.

2. Ibid.

3. Ibid., p. 19

4. J. Phair (1992), “1992 education report card,” Public Relations Journal, February, pp. 22-24, extract p. 22.

5. E. Dennis and C. Lamay (1993), "Introduction: Higher education in the information age," in E. Dennis and C. Lamay (Eds.), Higher Education in the Information Age, Transaction Publishers, New Brunswick, NJ, pp. 1-4.

6. J. Carey (1993), "The academy and its discontents," in E. Dennis and C. Lamay (Eds.), Higher Education in the Information Age, Transaction Publishers, New Brunswick, NJ, pp. 153-67.

7. G. Ratcliffe and R. Williams (1994), "What the numbers tell us," CASE Currents, January, pp. 14-15.

8. R. Netherton (1996), "How the public sees higher education," CASE Currents, May, pp. 10-11.

9. Stepp (2003), "Higher examination," op. cit. p. 20.

10. J. H. Daughdrill (1994), "Assessment is doing more for higher education than any other development in recent history," in J. Stark and A. Thomas (Eds.), Assessment and Program Evaluation, Simon \& Schuster Custom Publishing, Needham Heights, MA, pp. $63-4$.

11. J. Burness (1993), "Mixed (up) messages: Universities and the media," in E. Dennis and C. Lamay (Eds.), Higher Education in the Information Age, Transaction Publishers, New Brunswick, NJ, pp. 5-17.

12. G. C. Sands (2003), "Re-defining and re-positioning the counselor to higher education," Counselors to Higher Education Monographs, Public Relations Society of America, available at <http:// www.prsa.org/_Networking/che/monographs.asp>, pp. 1-4, quote p. 1 .

13. D. Hale (2001), "Public relations in higher education, a retrospective and forecast," Counselors to Higher Education Monographs, Public Relations Society of America, available at <http:// 
www.prsa.org/_Networking/che/monographs.asp>, pp. 1-4.

14. Ibid., p. 2.

15. Sands (2003), "Re-defining and re-positioning the counselor to higher education," op. cit; Hale (2002), "Public relations in higher education," op. cit.

16. S. Biagi (2003), Media Impact: An Introduction to Mass Media, Wadsworth/Thompson Learning, Belmont, CA.

17. Ibid.

18. Stepp (2003), "Higher examination, op. cit."

19. D. Jones (2000), "Media relations: Successfully positioning your institution," in P. M. Buchanan (Ed.), Handbook of Institutional Advancement, Council for the Advancement and Support of Education, Washington, DC, pp. 187-94, quote p. 193.

20. Ibid
21. J. E. Ross and C. P. Halstead (2001), "Feeding the media monster," in J. E. Ross and C. P. Halstead (Eds.), Public Relations and the Presidency, Washington, DC: Council for the Advancement and Support of Education, pp. 119-126, extract p. 119.

22. Hale (2002), "Public relations in higher education," op. cit.

23. Ross and Halstead (2001), "Feeding the media monster," op. cit.

24. Jones (2000), "Media relations: Successfully positioning your institution, op. cit."

25. Ibid.

26. Ross and Halstead (2001), "Feeding the media monster," op. cit.; Jones (2000), "Media relations," op. cit.

27. Jones (2000), "Media relations: Successfully positioning your institution,” op. cit., p. 193.

\section{Practitioner's Perspective}

Those of us who have spent our careers in higher education have witnessed firsthand the important role the media play in how our various constituencies view our institutions. Creating an environment on our campuses that engenders an effective media relations program is critical to our future. Colleges and universities are experiencing a highly competitive atmosphere-in student recruitment and donor support-both of which are highly influenced by the media. Media coverage of our institutions provides a "third party endorsement" of the messages that are communicated through our other outlets, such as alumni magazines, recruitment brochures, and annual reports. The obligation we have, as advancement professionals, is to communicate effectively with the media, developing relationships with the key newspaper and electronic journalists, so that we can be trusted in sharing the truth-in good times and in bad.

Peyronel raised a number of important aspects to consider when building a successful media relations program. First, media scrutiny of higher education is here to stay-and appropriately so. Higher education cannot rest above the public's desire to know the truth about our institutions. Colleges and universities need to be honest in sharing information. Additionally, since fewer reporters are now focused full-time on higher education, it is incumbent upon us to develop ongoing relationships with the reporters so that our messages are heard and articles written. Peyronel notes that however a journalist/reporter prefers to receive information from our institution is the "right way" to communicate with them. This cannot be discovered until one gets to know the journalists; therefore it is incumbent upon advancement professionals to learn this so that they can interact with the reporters in the most effective manner. Also, Peyronel recommends that integrated communications marketing strategies need to include a media relations component to be truly effective. 
Advancement professionals will need to continue to focus their attention on building good relationships with the media. The scrutiny of higher education is here to stay. Our constituencies deserve to know the truth about our colleges and universities. We need to develop our messages and share information with the media in a thoughtful, efficient, and effective manner in order to better serve our institutions, our students, and our communities.

Deborah A. W. Read

Vice President, University Advancement, Northern Kentucky University, Highland Heights, USA 